Seloka: Jurnal Pendidikan Bahasa dan Sastra Indonesia
UNNES (2) (2020): $168-175$
https://journal.unnes.ac.id/sju/index.php/seloka

\title{
The Influence of Genre Pedagogical and Content and Language Integrated Learning on Elementary Students' Writing Skills
}

\author{
Muhammad Khairurrozikin ${ }^{\bowtie}$, Wahyu Sukartinigsih, Heru Subrata
}

DOI: https://doi.org/10.15294/seloka.v9i2. 40099

Prodi Pendidikan Dasar, Program Pascasarjana, Universitas Negeri Surabaya, Indonesia

\begin{tabular}{l}
\hline Article Info \\
\hline History Articles \\
Received: \\
20 March 2020 \\
Accepted: \\
20 June 2020 \\
Published: \\
21 August 2020 \\
\hline Keywords: \\
Teaching materials, \\
write news text, local \\
wisdom
\end{tabular}

\begin{abstract}
The objectives of this study are (1) to find out and to present the evidence whether the pedagogical model of the genre affects the writing skills of elementary school students, (2) to know and present the evidence whether Content and Language Integrated Learning (CLIL) affects the writing skills of elementary school students, (3) to know and explain evidence whether the genre pedagogical model and Content and Language Integrated Learning (CLIL) jointly influence the writing skills of elementary school students. This research is a Pre-Experimental Design with One Group Pretest-Posttest Design. In this design, there is only one class that will be analyzed and measure the extent of students' writing skills before and after treatment. The results of the study are proven (1) that genre pedagogical model has a positive and significant effect on the writing skills of grade 5 elementary school students, (2) that the Content and Language Integrated Learning (CLIL) has a positive and significant effect on the writing skills of grade 5 elementary school students, (3) that the genre pedagogical model and Content and Language Integrated Learning (CLIL) jointly influence the writing skills of grade 5 elementary school students.
\end{abstract}

\footnotetext{
$\triangle$ Correspondence address:

Gedung CPD Unesa, Lidah Wetan, Surabaya, 60213

E-mail: muhammadkhairurrozikin.18023@mhs.unesa.ac.id

p-ISSN 2301-6744

e-ISSN 2502-4493
} 


\section{INTRODUCTION}

Language has a central role for intellectual, social and emotional development of students and it is a way of success in learning in all fields of study. Language learning is expected to help students get to know themselves, their culture, and other cultures, and help them express ideas and feelings. Moreover, language learning is expected to help students participate in communities by using its language, and the analytical and imaginative abilities within themselves (Depdiknas, 2006).

The purpose of language learning is to carry the language continuous process through listening, speaking, reading, and writing stages. The end of this purpose is to make students be able to implement language learning, express their ideas smoothly and clearly, and communicate effectively (learning to use language, learning about language, and learning through language)

The ability to think (literacy) of students in Indonesia is still weak. According to Program for International Student Assessment (PISA) (2018), students' ability to think in Indonesia is only at level 3. It is significantly different from other countries in the Southeast Asia region which are above Indonesia (OECD), 2015). The language learning model that is applied by Indonesia is still less precise and therefore, results that Indonesian students' literacy (thinking) skills is being less developed. Consequently, the improvement of Indonesian language skills through writing text skills in the form of stories and exposition texts needs to be implemented

The problems currently being experienced are based on observations and findings in the field, teaching writing carried out by the teacher is always associated with what activities students do while on vacation and do it at home. Writing activities that are done at home result in the learning process being ineffective and less meaningful for students. It is caused because students express their ideas only into their writing text without paying attention to the rules and correct writing concepts. This becomes a fundamental reason because the writing process is not an easy thing for students.

An appropriate model is needed in learning to write in order to produce a work or writing which contains character values. Such efforts can be made by applying two learning models that are suitable for integration. The genre pedagogical model and CLIL (Content and Language Integrated Learning) are two models that can be applied as an effort to optimally improve students' Indonesian language skills between improving the quality of the content of learning materials (content knowledge) and improving how to educate (pedagogical knowledge). In general, the models and approaches that are integrated in this study provide opportunities for students to play an active role. The active role of students is very important in the framework of forming a creative generation, which is able to produce something for the benefit of themselves and others. Creative is also intended for teachers to create diverse learning activities so that they meet various levels of student ability. Learning is not always emphasized or teacher-centered, but learning that is student-centered, or that is produced by students (Chan, 2002).

Content and Language Integrated Learning (CLIL) is an adequate approach to be applied to understand the material being studied as well as to expand the language skills used in learning (Coyle, 2008). The use of language in learning is not only an instructional medium, but can be the goal of the learning. It means improving language skills, both oral and written language skills. In general, language skills which include oral and written language skills are the basis for forming students' literacy skills.

Genre pedagogy (pedagogical knowledge) or understanding of how to educate can be defined as a socially recognized way of using language to achieve certain communicative goals. Genre is a process of social and cultural interaction that is the background for the creation of different types of texts (Yuen \& Heeseon, 2018). The steps of learning using this genre pedagogical model include building 
context, studying models, constructing guided, and constructing independently (Mahsun, 2013).

Students' writing skills need to be improved from an early age. Writing competence is a form of productive language proficiency which has great benefits for students. By writing, students can express ideas, thoughts and heart conditions during difficult and happy times, desires and feelings, as well as satire and criticism (Jayanti, Nuryatin, \& Mardikantoro, 2015). Elementary school is the right time to improve writing skills for students, in writing activities, but many requirements must be fulfilled, including meaningful, clear, or straightforward, being one unit, short and concise, and fulfilling linguistic rules to produce good writing. In this case, good writing is writing that contains character values (Sokhipah, Subyantoro, \& Mardikantoro, 2015

The decline in moral quality in Indonesian today, especially among students, demands character education. Schools are required to play their roles and responsibilities to instill and develop good values and help students shape and build their character with good values. Character education is directed to put pressure on certain values and help students to understand, pay attention to, and carry out these values in their own lives, one of which is through children's stories (Neina, Mardikantoro, \& Supriyanto, 2015).

Through the effort to create writing with character values, students are expected to be able to develop their character values. Character values that are instilled in students will become their own character. In addition, it affects the application of these values in their life as members of the community, and citizens who are religious, nationalist, productive and creative (Abidin, 2012)

Based on this phenomena, problems can be formulated and the objectives of this study are (1) to describe the influence of the genre pedagogical model on the writing skills of grade 5 elementary school students, (2) to explain the influence of CLIL on the writing skills of grade 5 elementary school students, and (3) describes the effect of genre pedagogy model and CLIL together on the writing skills of grade 5 elementary school students.

\section{METHOD}

This study is a pre-experimental design with a one-group pretest-posttest design model. In this study there was only one class group that had been determined. Acquisition of data begins first by giving a pretest to the group to be studied before treatment. This is done to determine the initial ability of the group before being given treatment and post-test to determine the effect after being given treatment.

The variables in this study are two independent variables and one dependent variable. The independent variable is the influence of the pedagogical model of genre $\left(\mathrm{X}_{1}\right)$ and CLIL $\left(\mathrm{X}_{2}\right)$. While the dependent variable in this study was the students' writing skills (Y). The relationship between the two variables in this study is a dual paradigm with two independent variables to look for influence between $\mathrm{X} 1$ and $\mathrm{X}_{2}$ on $\mathrm{Y}$ together using a multiple correlation (Sugiyono, 2017).

The sample in this study were 5 th grade students of SDN Sedatigede II, Sidoarjo. Data collection techniques in this study were divided into two, namely test and non-test techniques. The test technique is used to measure the ability of students in story writing skills. The test technique is carried out at the beginning and end of the treatment in the class that has been determined. The results of the ability to write story text are guided by the theme, paragraphs, character values, cover or impression, and mechanics. The non-test technique was used to determine the extent to which students were able to absorb the use of learning models and materials based on the genre pedagogical model and CLIL at the treatment stage. The non-test technique was obtained through a questionnaire and observation sheet.

The data analysis technique used in this study is a comparative description, namely comparing the results of the initial and final ability tests. Based on the data obtained, then analyzed and concluded whether there is a 
significant difference between the average value before and after treatment. The statistical analysis carried out in this study was carried out with the help of the SPSS 20 for windows computer program.

Before the data is analyzed, the analysis prerequisite test is firstly carried out as follows

The normality test used in this study was Kolomogrov Smirnov at the 5\% significance level. The rule used to determine whether the distribution is normal or not is if the significance value is $<0.05$ then the distribution is not normally distributed, conversely if the significance value is $>0.05$ then the distribution is normally distributed.

The multicollinearity test aims to test whether there is a correlation between the independent variables (independent). This test can be done to see the tolerance value and variance inflation factor (VIF). If the tolerance value approaches 1 and VIF is around 1 and does not exceed 10 then multicollinearity does not occur.

The heteroscedasticity test is to test whether there is an unequal variance and residuals from one observation to another. The heteroscedasticity test in this study uses the Glazer test on the basis of decision making if the significance value is more than 0.05 , the independent variable of this study is free from heteroscedasticity.

The autocorrelation test aims to test whether in a study using a linear regression model there is a correlation between usage errors in periods $\mathrm{t}$ and $\mathrm{t} 1$ (previous). If there is a correlation, then there is a problem called autocorrelation with the basis of decision making as follows: (1) if the DW value lies between the upper limit (du) and (4-du), then the autocorrelation coefficient is equal to 0 (zero), meaning there is no auto correlation; (2) if the DW value is lower than the lower limit (d1), then the autocorrelation coefficient is greater than 0 (zero), then there is a positive correlation; (3) if the DW value is greater than (4-dl), then the autocorrelation coefficient is smaller than 0 (zero), meaning there is a negative correlation; and (4) if the DW value lies between the limit (du) and the lower limit (dl), then the results are inconclusive.

Hypothesis testing in this study uses multiple regression analysis techniques. Multiple regression analysis technique is a regression equation using two or more independent variables (Santoso \& Ashar, 2005). To find out whether there is a significant effect of the independent variables on the dependent variable, there is a T-test (partial) to determine whether there is a partial influence between each independent variable on the dependent variable with a significance level of 0.05 . F-test (simultaneous) to find out whether there is a positive and significant influence between the variables $X_{1}$ and $X_{2}$ on the $Y$ variable together by comparing the significance of the $\mathrm{F}$ calculated value, on the basis of decision making, if the value of F-count $>$ F-table then there is the positive and significant influence between $X_{1}$ and $X_{2}$ on variable $Y$. The coefficient of determination $\left(\mathrm{R}^{2}\right)$ test basically measures how far the model's ability to explain the variation in the dependent variable. The coefficient of determination test in this study will use the coefficient of determination test adjusted to the value of Adjusted R Square.

The assessment of learning outcomes that will be used is guided by the development model of learning outcomes assessment published by the Ministry of Education and Culture, Directorate General of Secondary Basic Education, Directorate of Student Development in 2013. The assessment model is developed according to needs but still in accordance with the 2013 Curriculum. This assessment guide describes the scope of , techniques, and learning assessment instruments produce text. The expansion of the scope of attitude assessment is based on the basic competency characteristics of KI-1 and KI-2 for each subject, namely responsibility, mutual cooperation, and proactiveness (Kementrian Pendidikan dan Kebudayaan, 2013). 


\section{RESULT AND DISCUSSION}

Such learning process using the genre pedagogy model and CLIL is proven to have a positive and significant effect on students' writing skills. The genre pedagogical model and CLIL provide a new learning experience for students during the COVID-19 pandemic, the way the material is delivered and the stages carried out in learning increase students' motivation in learning. It is proven that the average value of the initial test obtained by students is 76.50 , while the average value of the final test is 86.00 . The highest score of students on the initial test was 85.00 and the lowest score was 60.00. While the highest score of participants in the final test was 95.00 and the lowest score was 70.00 .

Based on the results of the calculation with a sample of 20 students, it was found that the pre-test and post-test scores on students' writing skills had increased. There were students with an increase in value of 20 as many as 5 students, following an increase in scores of 10 and 15 as many as 4 students and 6 students with an increase in the value of 5 , while there was 1 student who did not experience a change from the pre-test and post-test scores.

The following data is tabulated and then analyzed using the SPSS 20 computer program for windows and the following results are obtained: (1) a significance value of 0.890 is obtained in the normality test using the Kolomogrov Smirnov technique with a value of $0.890>0.05$, on the basis of decision making if the significance value $>0$ Then the data is normally distributed. Thus, it can be concluded that the data obtained in this study were normally distributed; (2) in the multicollinearity test which aims to test whether there is a correlation between the independent variables, the Variance Inflation Factor (VIF) value of 1,142 or smaller than 10 is obtained, on the basis of decision making if the VIF value is around 1 and does not exceed 10 then it does not exceed 10 multicollinearity occurs in the regression model. So it can be concluded that there is no multicollinearity between the independent variables in the regression model; (2) in the heteroscedasticity test which aims to test whether there is an unequal variance and residuals from one observation to another. Obtained a significant value for the hetrokedesticity test of 1.00 or greater than the significance value of 0.05 for variables $X_{1}$ and $\mathrm{X}_{2}$. The heteroscedasticity test in this study uses the Glasjer test on the basis of decision making if the significance value is more than 0.05 , the independent variable of this study is free from heteroscedasticity. Based on this, it can be concluded that if there is no heteroscedesity problem in the independent variables; (3) in the autocorrelation test, which aims to test whether in the study using a linear regression model there is a correlation between usage errors in periods $t$ and $\mathrm{t} 1$ (previously). Obtained $\mathrm{DW}$ value in the autocorrelation test of 2.221, with two independent variables and a sample size of 20 , the table value $\mathrm{dl}=1.0003$ and $\mathrm{du}=1.5673$, so that $4-\mathrm{dl}=2.996$ and $4-\mathrm{du}=2.4633$. based on the results of these calculations, the DurbinWatson value is between du and 4-du. Based on the basis of decision making, it can be concluded that there is no autocorrelation in the regression equation.

Moving on from the results of the analysis prerequisite test, the data obtained can be continued with the hypothesis testing stage. In this study, hypothesis examiners used multiple linear regression test. The test results are to answer the partial and simultaneous hypothesis in this study.

Hypothesis 1: There is a positive and significant effect between genre pedagogical models on the writing skills of grade 5 elementary school students.

The test results show that $\mathrm{T}$-count $=$ 3,610> T-table, $\mathrm{T}$-table $=\mathrm{t}(\alpha / 2 ; \mathrm{n}-\mathrm{k}-\mathrm{l})=(0.025$; 17) $=2.10982$. Means that the value of T-count $>$ T-table value $(3.610>2.10982)$, then $\mathrm{HO}$ is rejected and $\mathrm{H} 1$ is accepted. Based on this result, the hypothesis, which says that there is a positive and significant effect between the genre pedagogical models on the results of writing stories for grade 5 students, is partially accepted. This model makes students actively find out and 
increase students' curiosity about the type of text and fosters student motivation to produce text in the form of simple stories. The use of genre pedagogical models in the learning process creates reciprocity between students and teachers, whichare reflected in each syntax or learning activity using the genre pedagogy model. This causes students to feel motivated to follow the learning process and improve their writing skills. Although learning is carried out using an online system, students actively respond to everything ordered by the teacher.

Hypothesis 2: there is a positive and significant effect between Content and Language Integrated Learning (CLIL) on the writing skills of grade 5 students.

The test results show that $\mathrm{T}$-count $=$ 5.006 $>$ T-table, T-table $=\mathrm{t}(\alpha / 2 ; \mathrm{n}-\mathrm{k}-\mathrm{l})=$ $(0.025 ; 17)=2.10982$. It means that the value of T-count $>$ T-table value (5.006> 2.10982), then $\mathrm{H} 0$ is rejected and $\mathrm{H} 2$ is accepted. Based on this result, the hypothesis, which says that there is a positive and significant influence between Content and Language Integrated Learning (CLIL) on the results of writing stories for grade 5 students, is partially accepted. The results obtained by students in writing skills using Content and Language Integrated Learning (CLIL) have good results. The learning processis carried out using the stages in CLIL, namely, content, communication, cognition and culture.

Hypothesis 3: the genre pedagogical model $\left(\mathrm{X}_{1}\right)$ and Content and Language Integrated Learning (CLIL) $\left(\mathrm{X}_{2}\right)$ together have an effect on the writing skills of grade 5 students.

The calculation results show that the Fcount value is 29,028 with the F-table value is 3.59 , so that the F-count> F-table, the F-table value is obtained with $\mathrm{f}(\mathrm{k} ; \mathrm{n}-\mathrm{k})=(2 ; 18)$ so it can be seen in the F-table distribution at a significant value of $0.05=3.59$. Thus the $\mathrm{F}$ count $>$ F-table (29.028> 3.59) and the significance level of $0.000<0.05$, then $\mathrm{H}_{0}$ is rejected and $\mathrm{H}_{3}$ is accepted, thus it can be concluded that the hypothesis which reads the pedagogical model of genre $\left(\mathrm{X}_{1}\right)$ and Content and Language Integrated Learning (CLIL) $\left(\mathrm{X}_{2}\right)$ jointly affects the writing skills of grade 5 students simultaneously accepted.

In this study, the coefficient of determination test was also carried out to measure how far the model's ability to explain variations in the dependent variable, the coefficient of determination is adjusted to the value of Adjusted $\mathrm{R}$ Square. Obtained the Ajusted R Square value of 0.747. This means that the ability of the independent variables in explaining the dependent variable is $74.7 \%$, the remaining $25.3 \%$ is explained by other variables not discussed in this study such as students' initial abilities, level of imagination and others.

The findings above explain if the learning model combined with the right approach will have a positive and significant impact on students' writing skills and character. (Neina, Mardikantoro, \& Supriyanto, 2015) in the research development of enrichment books to write children's stories with character values based on CLIL, the results of increasing scores before and after learning using enrichment books to write children's stories based on characters based on CLIL. The book developed uses CLIL stages that allow students to increase interest in learning and improve character education.

In general, the obstacles experienced in this study include matters relating to the learning process carried out online due to the COVID-19 pandemic. This resulted in several stages in learning that could not be carried out optimally. But even so researchers try to provide maximum potential to obtain the expected data and research results. Within its limitations, researchers continue to uphold the validity values of a study that has been carried out.

Based on the influence and findings that the researcher encountered, the researcher speculated that if the learning model was balanced with good material, it would certainly have a positive and significant effect, this is evident from the research that has been carried out. Increasing students' writing skills cannot be separated from reciprocity and student motivation to continue learning. The use of learning models in the learning process can generate new desires and interests, generate 
motivation and stimulation of learning activities and even bring psychological influences on students (Hamalik, 2008).

\section{CONCLUSION}

Based on the results of the research and discussion presented in the previous section, several conclusions can be drawn as follows.

There is a positive and significant effect after the application of the pedagogical model of genre and Content and Language Integrated Learning (CLIL), on the story writing skills of fifth grade students of SD Negeri Sedatigede II, Sidoarjo. This is proven by the increase in the results of writing skills after the application of the pedagogical model of genre and Content and Language Integrated Learning (CLIL).

The genre pedagogical model and Content and Language Integrated Learning (CLIL) have an effect on the story writing skills of fifth grade students of SD Negeri Sedatigede II, Sidoarjo. This proves that the learning model with an integrated approach will foster student interest and motivation. This interest and motivation can improve the writing skills of fifth grade students of SD Negeri Sedatigede II, Sidoarjo.

\section{REFFERENCES}

Abidin, Y. (2012). Pembelajaran Bahasa Berbasis Karakter. Bandung: Refika Aditama.

Chan, D. W. (2002). Fostering Creativity in Schools in Hong Kong: Issue And Challenges From A System Perspective. Education Journal. Volume 30 number 1, 118.

Coyle, D. (2008, Oktober). Content and Language Integrated Learning: Motivating Learners and Teachers. Retrieved November 10, 2019. http://blocs.xtec.cat.clilpractiques1/file/ 2008/11/slrcoyle.pdf

Depdiknas. (2006). Standar Isi. Jakarta: Badan Standar Nasional Pendidikan.

Hamalik, O. (2008). Proses Belajar Mengajar. Jakarta: Bumi Aksara.
Jayanti, T., Nuryatin, A., \& Mardikantoro, H. B. (2015). Pengembangan Buku Pengayaan Menulis Cerita Biografi Bermuatan Nilai-Nilai Pendidikan Karakter Bagi Peserta Didik Kelas VIII SMP. Seloka: Jurnal Pendidikan Bahasa dan Sastra Indonesia, Volume 4(2), 65-71. https://journal.unnes.ac.id/sju/index.ph $\mathrm{p} /$ seloka/article/view/9862

Kementerian Pendidikan dan Kebudayaan. (2013). Materi pelatihan Guru Implementasi Kurikulum 2013. Kemendikbud. Jakarta: Kementerian Pendidikan dan Kebudayaan.

Mahsun. (2014). Teks dalam Pembelajaran Bahasa Indonesia Kurikulum 2013. Jakarta: Raja Grafindo Persada.

Neina, Q. A., Mardikantoro, H. B., \& Supriyanto, T. (2015). Pengembangan Buku Pengayaan Menulis Cerita Anak Bermuatan Nilai Karakter Berdasarkan Content And Languange Integrated Learning (CLIL) Untuk Siswa Sekolah Dasar Kelas Tinggi. Seloka: Jurnal Pendidikan Bahasa dan Sastra Indonesia. Volume 4(2), 50-57. https://journal.unnes.ac.id/sju/index.ph $\mathrm{p} /$ seloka/article/view/9860

OECD. (2015). PISA. Dipetik November 19, 2019, dari Programme for International Student Assesment (PISA): www.oecd.org/pisa/PISA-2015Indonesia.pdf

Santoso, P. B., \& Ashar. (2005). Analisisi Statistik dengan Microsof Excel \& SPSS. Yogyakarta: Andi Offset.

Sokhipah, W. L., Subyantoro, \& Mardikantoro, H. B. (2015). Keefektifan Model Show Not Tell dan Mind Map Pada Pembelajaran Menulis Teks Eksposisi Berdasarkan Minat Peserta Didik Kelas X SMK. Seloka: Jurnal Pendidikan Bahasa dan Sastra Indonesia. Volume 4(2), 72-77. https://journal.unnes.ac.id/sju/index.ph $\mathrm{p} / \mathrm{seloka/article/view/9863}$

Sugiyono. (2017). Metode Penelitian Pendidikan (Pendekatan Kuantitatif, Kualitatif, dan $R \& D)$. Bandung: Alfabeta, CV. 
Muhammad Khairurrozikn, et al./

Seloka: Jurnal Pendidikan Bahasa dan Sastra Indonesia 9 (2) (2020) : 166 - 175

Yuen, L., \& Heeseon, J. (2018). Impact of genre-based pedagogy on students' academic literacy development in Content and Language Integrated Learning (CLIL). Journal Pedagogi and
Linguistic. $\quad$ Volume 47, Pages 36-46.

Retrieved from
https://doi.org/10.1016/j.linged.2018.08 .001 